\title{
Clitics and Clause Structure
}

\author{
Cleo Condoravdi \\ XEROX PARC and Stanford University \\ Paul Kiparsky \\ Stanford University
}

\begin{abstract}
In late Medieval Greek and many modern dialects, pronominal clitics are syntactically adjoined to an IP projection. In another set of dialects they have become syntactically adjoined to a verbal head. In the most innovating dialects (which include Standard Greek) they are agreement affixes. Extending the Fontana/Halpern clitic typology, we propose a trajectory of lexicalization from $\mathrm{X}^{\max }$ clitics via $\mathrm{X}^{0}$ clitics to lexical affixes. The evolution of clitic placement also reveals the rise of a composite functional projection $\Sigma$ P.
\end{abstract}

Keywords: clitics, functional projections, prosodic inversion, topic, focus, typology, Greek dialects, medieval Greek, historical syntax, syntactic change, Pontic, Cappadocian.

\section{Introduction}

\subsection{Syntactic change in Greek}

Research on syntax has demonstrated the utility of a comparative-historical approach which uses co-variation and co-change to diagnose structural relationships. Such an approach is particularly suited to a language such as Greek, which during its over three millennia of recorded history has changed radically in its syntax. Moreover, Greek shows considerable diversity of dialects. While nearly all are descended from the Koiné standard of the Hellenistic period, they nevertheless diverge syntactically in significant ways.

This study addresses the dialectal variation in phrase structure and word order, especially as it relates to the verbal functional projections, and attempts a preliminary reconstruction of its historical origins. ${ }^{1}$ As is well known, cliticization is one of the best diagnostics of clause structure in languages with relatively free word order, and much of our argumentation will be based on the positioning of verbal argument clitics. We show that, with respect to the properties of clitics themselves, modern Greek dialects fall into three major syntactic types. Our analysis locates the difference between them in the status of the clitics as, respectively, $X^{\max }, X^{0}$, and lexical. We argue that these stages, in that order, reflect a shift from syntactic to lexical status in two steps. ${ }^{2}$ 
Clitic placement converges with other syntactic evidence in identifying distinct syntactic projections for Tense and Mood, namely TNSP and $\Sigma$ P. These syntactic projections, we suggest, were not present in the stage of Greek which obeyed Wackernagel's Law, but had emerged, in that order, at least by the medieval period. Thus Greek has undergone a development similar to that which has been proposed for other branches of Indo-European (Kiparsky 1995, 1997, Deo 2001), whereby the realization of functional categories shifted from verbal inflections to syntax.

The fact that the evolution of Greek syntax, in these respects at least, broadly parallels that of other Indo-European languages, is of some interest in the context of recent controversies on the actuation of syntactic change. On one view, syntactic change proceeds in small but discrete steps; this view is often associated with the assumption that change has a structurally/functionally motivated directionality. An opposing view (Lightfoot 1999) advocates "catastrophic" reanalysis with no intrinsic directionality as the basic mechanism of change. Our findings tend to support the former view. The lexicalization/grammaticalization of clitics and the renewal of morphological categories in the syntax through the rise of new syntactic functional projections are classic instances of unidirectional (or at least typically unidirectional) change which, as the Greek data confirm, proceeds in small but discrete increments. ${ }^{3}$

\subsection{The clitic typology}

In modern Greek, verbal argument clitics are always adjacent to a finite verb, but in some dialects they always follow or always precede it, and in others they precede or follow it depending on what other material is present on the left periphery of the clause. We argue that clitics in modern Greek dialects are of three distinct types: ${ }^{4}$

Type A (Eastern type): $\mathrm{X}^{\max }$ clitics, syntactically adjoined to a maximal projection. They appear, in invariant form, both in preverbal and postverbal position depending on the syntactic context; under our proposed analysis, all are enclitic.

The clitics of the following dialects are of the $\mathrm{X}^{\max }$ type: inland Asia Minor (Cappadocia, Bithynia), the Cyclades, some Dodekanese islands (Karpathos, Kos, Astipalaia), two localities on Lesbos (Ajassos, Plomari), the Tauro-Roumeic dialects of Ukraine (Marioupoli/Azov). Late Medieval Greek is of this type as well.

Type B (Pontic/Kozani type): $\mathrm{X}^{0}$ clitics, syntactically adjoined to a lexical head.

This type of clitic occurs in two forms. $\mathrm{X}^{0}$ enclitics are found in the Pontic dialects, originally spoken on the Black Sea coast both in Turkey (until 1922, with a small population of Greek-speaking Moslems remaining around Of in Turkey) and in Russia. $\mathrm{X}^{0}$ proclitics are found in Kozani in Greek Macedonia.

Type C (Western type): lexical clitics, affixed to words. 
The clitics of standard Greek are prefixes which attach to prosodic words in the lexicon. So are those of most modern dialects of mainland Greece and of the Western islands, as well as the dialects of Italy.

In general, all clitics in any given dialect behave the same way, regardless of gender, person, and number. All clitics that are arguments of a finite verb are consistently of type A, type B, or type C. ${ }^{5}$ Therefore we can also speak of type A, type B, and type C dialects. $^{6}$

Halpern \& Fontana 1994 propose a two-way distinction between $\mathrm{X}^{\max }$ and $\mathrm{X}^{0}$ clitics. $\mathrm{X}^{\max }$ clitics are maximal projections which adjoin to a phrasal projection and do not require a prosodic host of a particular syntactic category. $\mathrm{X}^{0}$ clitics, by contrast, require a host of a particular syntactic category. We take this to be the main characteristic of $\mathrm{X}^{0}$ clitics. Halpern \& Fontana, moreover, claim that $\mathrm{X}^{0}$ clitics are in effect inflectional affixes. We will argue that their category of $\mathrm{X}^{0}$ clitics conflates two distinct types of clitics, those that are syntactically adjoined to a lexical head (for which we reserve the term $\mathrm{X}^{0}$ clitics) and those that combine with a host word in the lexicon (which we call affixal clitics). ${ }^{7}$

\subsection{The phrase structure}

Our analysis of clitic positioning in type A dialects is based on certain assumptions about their phrase structure. In this section we briefly motivate those assumptions.

The clause structure of type A dialects is strikingly similar in certain respects to that of standard Modern Greek (SMG). Specifically, they share the following properties with SMG:

[1] a. they allow verb-initial clauses;

b. they have the same distribution of negation and mood particles;

c. a single focused XP or a single emphatic negative element can appear preverbally within the IP; ${ }^{8}$

d. they allow for multiple topics, which trigger clitic doubling if they are nonsubject arguments, as in SMG $;^{9}$

e. a preverbal focused XP or emphatic negative is always to the right of any preverbal topics;

f. no argument or adjunct XP can intervene between a preverbal focused XP or emphatic negative and the verb.

The discussion of the distribution of clitics in section 2 illustrates all these properties.

[2] illustrates Topic - Focus - Verb order (properties (c) and (e)) for Cappadocian, a type A dialect, and shows the parallelism with standard Modern Greek. Capitalization marks the emphatic negative element, and clitics are underlined. 


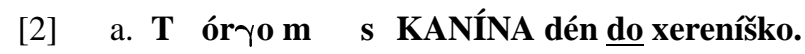
the work mine to noone not it entrust 'I entrust my work to noone.' (Axos, Cappadocia; M \& K 182)

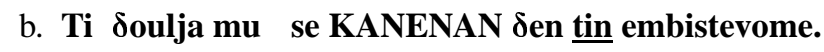
the work mine to noone not it entrust 'I entrust my work to noone.' (SMG)

We assume, uncontroversially, that arguments originate within the VP, and that finite verbs in Greek move from V to the head of TNSP. Following Laka 1990 and Piñon 1993, we assume that the highest inflectional projection is $\Sigma \mathrm{P}$, a composite of NegP, MoodP, and FocusP. It is headed by negation (mi, Sen, mina), if present, and by modal particles $(n a, \theta a, a s)$. Focused XPs or emphatic negatives can move to its specifier position. Modern Greek has no V-to-C movement (Drachman \& Klidi 1992), hence no word order asymmetry between main clauses and subordinate clauses. Topicalization is adjunction to the highest IP projection (our $\Sigma$ P) and to CP (Philippaki-Warburton 1985, Tsimpli 1995 among others).

For all Greek dialects with $\mathrm{X}^{\max }$ clitics we posit the phrase structure in [3] (for economy of space, adjunction of topics to $\Sigma \mathrm{P}$ and to $\mathrm{CP}$ is not shown).

[3]

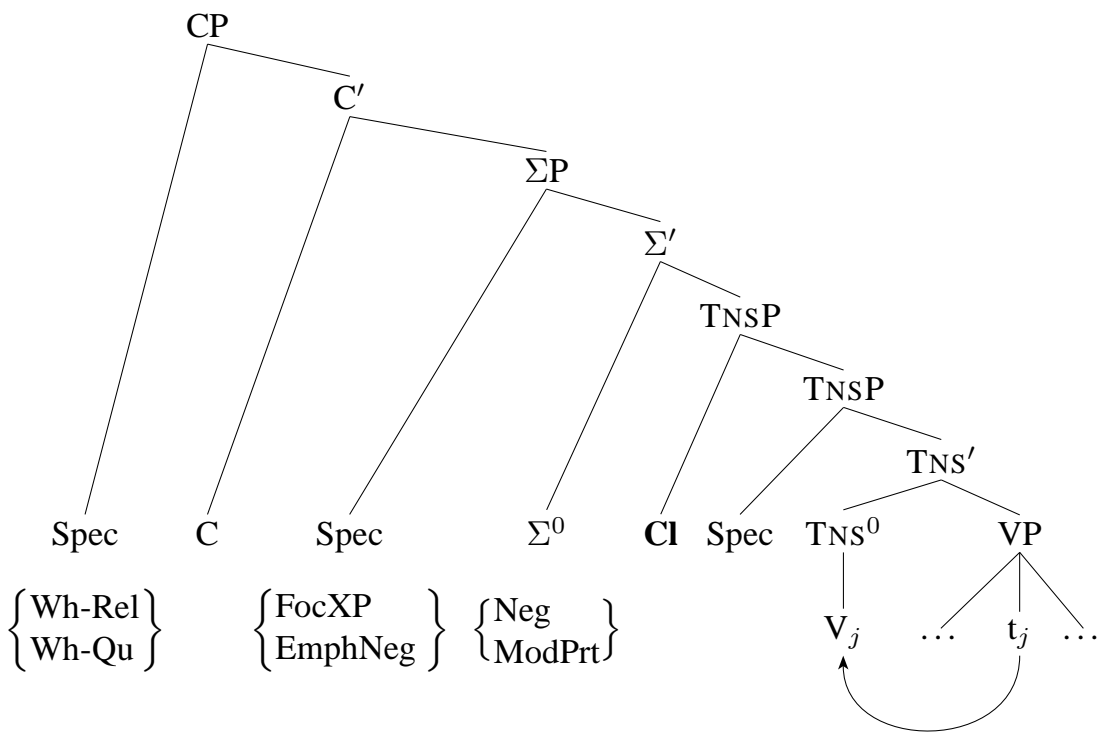

We assume that clitics adjoin to TNSP, and that [SPEC,TNSP] remains empty. ${ }^{10}$ We are agnostic as to whether there are functional projections other than the ones we have indicated in [3]. ${ }^{11}$ We leave for further investigation the question whether nonfocused preverbal subjects appear in $[$ SPEC, $\Sigma$ P]. Preliminary indications suggest dialectal variation on this point, which (in type A dialects at least) should correlate with clitic positioning, according to our analysis. 


\section{Type A Dialects: $\mathbf{X}^{\max }$ Clitics}

\subsection{Clitics in A dialects: the descriptive generalizations}

In type A dialects, clitics appear immediately before or immediately after a finite verb. The basic distribution of clitics was worked out by Dawkins in his remarkable 1916 study of the now extinct Cappadocian dialects. Additional observations were made by Janse 1998, based on Dawkins' texts. Their rules can be summarized as follows:

[4] a. Main rule: Clitics directly follow V.

b. Special rule: Clitics directly precede $\mathrm{V}$ in the following cases:

1. after a negation,

2. in subjunctive or future tense clauses,

3. after interrogative wh-phrases,

4. after relative pronouns (Janse 1998),

5. after subordinating complementizers (Janse 1998),

6. after preverbal phrases in focus (Janse 1998).

These generalizations hold not only for Cappadocian, but for our type A dialects in general. We illustrate them here with data from the Tauro-Roumeic dialects of Mariupoli/Azov (South-Eastern Ukraine), cited from Pappou-Zouravliova 1999.

\section{[5] a. Mi zmonát namí ankévit.} not forget-2pl NA me remember-2pl

'Do not forget to remember me.'

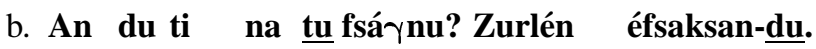
with the what NA it kill-1sg with effort killed-3pl it 'What am I going to kill it with? With difficulty they managed to kill it.'

Significantly, all these dialects conform to the generalizations in [1], which diagnose the presence of at least one functional IP projection above TNSP, according to us $\Sigma$ P.

Assuming the phrase structure in [3], the distribution of postverbal clitics in dialect $\mathrm{A}$ is characterized by the following descriptive generalization:

[6] Clitics are postverbal if and only if there is no non-adjoined constituent within the same CP to the left of the clitic.

We show below that the syntactic assumptions in section 1.3 account for the descriptive generalization [6]. To do that, we demonstrate that, under these assumptions, clitics are postverbal exactly when they cannot be preverbal because there is no host for them in that position. 


\subsection{Explaining the distribution}

On the surface, it appears that in Type A dialects the clitic or the verb appear in at least two different syntactic positions. We argue that the clitic and the verb always appear in the position indicated in [3]. Clitics are adjoined to a functional projection whose head the verb moves to, namely TNSP. The distribution of clitics is a consequence of their syntactic and prosodic properties. Clitics prosodically subcategorize for a prosodic word on their left within the same $\mathrm{CP}$. Adjoined constituents are not visible for cliticization. ${ }^{12}$ If there is no available prosodic host to their left, they encliticize onto the adjacent word on their right by PROSODIC INVERSION (Halpern 1995). ${ }^{13}$

We view prosodic inversion as an optimization strategy which ensures best satisfaction of the cliticization requirement plus the twin syntactic constraints that input order of clitics must be preserved and that clitics remain within the same $\mathrm{CP}$. According to our proposal, then, postverbal positioning of clitics is the special case (contrast the formulation in [4], which in effect treats it as the default). ${ }^{14}$

An interesting alternative is the idea of Bošković 2001 that clitics are placed by the syntax in more than one position, and that phonological constraints function as filters which select among those positions. Bošković shows that it works straightforwardly for Serbo-Croatian. For Bulgarian clitics, which are similar to the clitics of type A Greek dialects, Bošković suggests that clitics form a movement chain whose head is pronounced, except if this would lead to a phonological violation, in which case some lower copy of the clitic in the chain is pronounced. This account has the conceptual virtue of locating all movement in the syntax, and makes some interesting empirical predictions. It may work for the Greek $\mathrm{X}^{\max }$ dialects. We do not adopt it here because we do not see how to extend it to the dialects treated below, including crucially the Kozani dialect (section 5.4).

It would be desirable to have a theory of clitic placement in which all systems would find their place. From the Optimality-Theoretic perspective, the difference between the Serbo-Croatian system and the Greek/Bulgarian system can be seen as a matter of constraint domination; in Serbo-Croatian, syntactic constraints dominate the phonological constraints; in type A Greek, phonological constraints conversely dominate the syntactic constraints, forcing prosodic inversion.

A less satisfactory alternative is that the postverbal positioning of clitics is due to syntactic factors alone, such as verb movement over the clitic. For instance, one could assume that the verb moves to $\Sigma^{0}$ if the $\Sigma$ and C projections are devoid of any lexical material. What would be the syntactic motivation of such a movement? Terzi 1999, in an analysis of the positioning of Cypriot clitics, which appears to be like that of type A dialects, argues that the clitics need a syntactic licenser and in the absence of any other licenser the verb moves to the highest projection within the IP, in her analysis the MoodP, in order to license the clitics. One reason we do not adopt this proposal is that the motivation for syntactic licensing seems rather weak. The set of licensers includes both functional heads, like negation, modal particles, and complementizers, 
as well as heads of non-functional projections, such as the head of a preverbal focus phrase or of a wh-phrase. It would be a strange syntactic licensing requirement that could be satisfied by so disparate a set of licensers. ${ }^{15}$

\subsection{Preverbal Clitics}

Clitics are preverbal if and only if there is some non-adjoined constituent within the same CP to the left of the clitic. This may be a complementizer (in $\mathrm{C}^{0}$ ), a Whelement (in [Spec, CP]), a negative or modal particle (in $\Sigma^{0}$ ), or a focused constituent (in $[S p e c, \Sigma P]$ ). We take up each of these cases in turn. (As before, the clitics are underlined in our examples.)

\subsubsection{Complementizers}

The first prediction is that a lexical (overt) complementizer in $\mathrm{C}^{0}$ hosts a clitic which is syntactically to its immediate right. The examples in [7] demonstrate this preverbal positioning of the clitic after a variety of subordinating conjunctions. Note the contrast in clitic ordering between the two clauses in $[7 \mathrm{c}, \mathrm{g}]$.

\section{[7] a. Óp to páišge, írte éna binár kundá} while him take-PastImp-3sg came-3sg a spring near

'As he was taking him, he came near a spring.' (Ulaghatsh, Cappadocia; D 366)

b. ton do émaxen

when it learned-3sg

'when he learned it' (Axos, Cappadocia; M \& K 216)

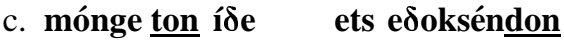

when him saw-3sg out sent-3sg away him

'When he saw him, he threw him out.' (Demirdesi; Dang 174)

d. óspu túpan i dáskalí tu

until him said-3pl the teachers his

'until his teachers told him.' (Astypalaia, Dodekanese; DD 56)

e. Өaró pos táfae ta pitákja

believe-1sg that them ate-3sg the little pies

'I believe that he ate the pies.' (Pyli, Kos, Dodekanese; DD 230)

f. to pultín tu $\delta$ ndzamantsú pu múferes

the bird the-Gen diamond-Gen that me brought-2sg

'the bird with the diamond that you brought me' (Astypalaia, Dodekanese; DD 59) 


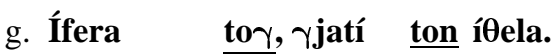

brought-1sg him because him wanted-1sg

'I brought him because I wanted him.' (Karpathos, Dodekanese; Minas 1970)

\subsubsection{Wh-phrases}

In relative clauses and in matrix or embedded wh-interrogatives, the specifier of $\mathrm{CP}$ is occupied by a relative pronoun or by an interrogative wh-phrase. Therefore, a clitic will always appear preverbally in relative clauses, as in [8a], or in wh-questions, as in $[8 \mathrm{~b}, \mathrm{c}]$. As in Standard Modern Greek, the (CP-adjoined) topic in [8c] is to the left of the wh-element (in [Spec,CP]).

[8] a. op tó draná

whoever it sees-3sg

'whoever sees it' (Axos, Cappadocia; M \& K 57)

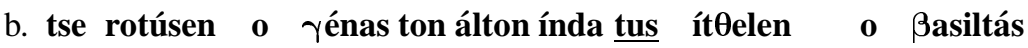
and asked-3sg the one the other what them wanted-3sg the king 'and they were asking each other what the king wanted them for' (Astypalaia, Dodekanese; DD 57)

c. Eto to beír čís to épken aúča?

this the stallion who it made-3sg thus

'Who made this stallion like this?' (Delmeso, Cappadocia; D 314)

\subsubsection{Negation and modal particles}

Negation and modal particles, we assume, are heads of $\Sigma$ P. Therefore, when such a particle is present, the rightmost lexically filled position before the clitic is $\Sigma^{0}$, which hosts the clitic; hence no prosodic inversion is necessary. Observe the contrast in clitic order between the two clauses in [9e].

[9] a. Túči čin góri zarjaní tu enéka rén čin a áápisi this the daughter present his wife not her love-3sg 'This daughter his present wife does not love.' (Silli; D 300)

b. epsé $\quad$ é se kratsam yesterday not you kept

'Yesterday we didn't put you up' (Demirdesi; Dang 176)

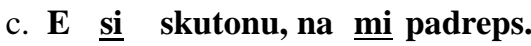

not you kill-1sg NA me marry-2sg

'I won't kill you so that you find me a wife.' (Plomari, Lesvos; K 492) 


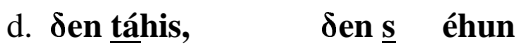

not them have-2sg not you have-3pl

'Let it go and it will let you go.' (Asphendiou, Kos, Dodekanese; DD 229)

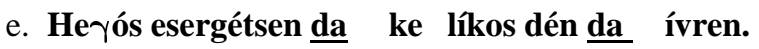

God protected them and wolf not them found

'God protected them and no wolf found them.' (Axos, Cappadocia; M \& K 188)

f. ás to piáso, ás to kópso, ke kalá ás to fá $\mathbf{0}$

AS it catch-1sg AS it kill-1sg and well AS it eat-1sg

'Let me catch it, let me kill it, and let me eat it right up.' (Ulaghatsh, Cappadocia; D 366)

According to our analysis, a preverbal clitic encliticizes onto the element on its left rather than procliticizing onto the verb. Striking evidence for this comes from mood particles which do not constitute prosodic words on their own, but do together with a clitic (active subcategorization, Inkelas 1989, Halpern 1995, Bošković 2001:160). For example, in the Cappadocian dialect of Ulaghatsh, $n a$ is stressed just in case a clitic follows it: ${ }^{16}$

a. Deré ßaßá m na ért, ge ná se rotíš ... now father my NA come-3sg and NA you ask-3sg

'Now my father will come and will ask you.' (Ulaghatsh, Cappadocia; D 366)

b. na ítose koundá $m$, to gaidúr ná to pjásoum ton, ké ná NA were-2sg near me the donkey NA it catch-1pl were-3sg and NA to pulísum ton, na parum lio kirjas... Ná to éfa $\gamma a ́ m$ sell-1pl it were-3sg NA get-1pl little meat ... NA it eat-1pl

ton.

were-3sg

'Had you been by me, we would have caught the donkey, we would have sold it to get a little meat. ... We would have eaten it.' (Ulaghatsh, Cappadocia; D 366)

\subsubsection{Focus}

Preverbal focus and emphatic negatives are housed in [Spec, $\Sigma \mathrm{P}]$. In [11] and [12] such a focused element constitutes the rightmost pre-clitic position with lexical material. The examples in [12] are answers to wh-questions, with the focused phrase corresponding to the wh-phrase of the question.

a. [Foc Polí ] do séßdinišge

much him loved-3sg

'She loved him much.' (Ulaghatsh, Cappadocia; D 366) 
b. [FOC Kalá ] ton rélasa.

well him tricked-1sg

'I tricked him well.' (Demirdesi; Dang 190)

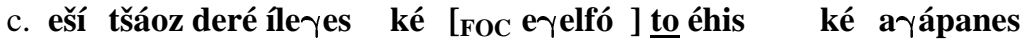
you until now said-2sg and brother it have-2sg and loved-2sg to.

it

'Up until now you were saying it (the deer) was your BROTHER and you loved it.' (Axos, Cappadocia; M \& K 192)

[12] a. Ého éna korič, k [Foc ekíno ] tópken have-1sg a daughter and she it said 'I have a daughter and SHE said it.' (Delmeso, Cappadocia; D 314)

b. [FOC I $\gamma$ ó ] tun án'ksa

I him undressed-1sg

'I undressed him.' (Plomari, Lesvos; K 493)

\subsubsection{Topic versus focus}

A topic alone never attracts a clitic to the preverbal position. On the other hand, elements within $\Sigma$ P, such as focus, modal particles and negation, which follow preverbal topics, always attract the clitic to the preverbal position. [13] provides a minimal contrast. All three examples have a nominalized clausal complement in topic position, as can be seen by the presence of clitic doubling. [13a] has an empty $\Sigma \mathrm{P}$, hence a postverbal clitic, while [13b] has the specifier of $\Sigma \mathrm{P}$ lexically filled, and [13c] has the head of $\Sigma \mathrm{P}$ lexically filled; in these the clitic is preverbal.

[13] a. [TоP to semayéften ] ípan mas ta (TOPIC) that got-3sg engaged told-3pl us it

'That he got engaged, they told us about it.'

(Axos, Cappadocia; M \& K 85)

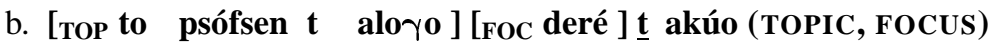
that died-3sg the horse now it hear

'That the horse died, I only heard it now.'

(Axos, Cappadocia; M \& K 85)

c. [TOP to na razandóso útsa pollá ] dén d ómza (TOPIC, NEG) that NA win-1sg thus many not it hoped

'That I would win so many, I didn't hope for it.' (Axos, Cappadocia; M \& K 85) 


\subsection{Postverbal clitics by prosodic inversion}

When the specifier and head positions of $\mathrm{CP}$ and $\Sigma \mathrm{P}$ are empty, minimal compliance with the requirement that the clitic must encliticize onto something forces the clitic to be placed after the first word, which, given the syntax, is the verb (prosodic inversion). The simplest case of postverbal clitics, illustrated in [14] by examples from four type A dialects, arises when the clitic is syntactically CP-initial.

\section{[14] a. Púlsa ta ta dévja.}

sold-1sg them the Devs

'I sold them to the Devs (spirits).' (Ulaghatsh, Cappadocia; D 378)

b. Vreíšten do ké gelétzepsan.

called-3sg her and talked-3pl

'He called her and they talked.' (Axos, Cappadocia; M \& K 216)

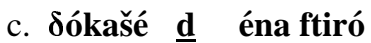
gave-3pl him a wing

'They gave him a wing' (Plomari, Lesvos; K 490)

\section{d. Ekamé-mas-to énas ftoxós үéros}

made us it a poor old man

'A poor old man made it for us.' (Demirdesi; Dang 176)

For reasons which remain to be explored, cliticization is blocked across an adjunction boundary. A clitic following an adjoined constituent undergoes prosodic inversion in Type A dialects. Adjunction occurs in coordination and topicalization. A clitic which syntactically follows a conjunction, such as ke/tse/če 'and' and amé 'but', must undergo prosodic inversion:

[15] a. Tóra metánjosa, ké ksomoloúme sú to now repent-1sg and confess-1sg you it 'Now I repent and I confess it to you.' (Pyli, Kos, Dodekanese; DD 233)

b. ̌́ ékani dun limn and made-3sg him lake 'and turned him into a lake.' (Ajassos, Lesvos; K 485)

c. Amé nžuloftoná ton $t$ afendikón tu tsé $\delta$ nžóxni to but is jealous him the master his and send-3sg away him and tells $\underline{\text { tu }}$ him

'But his master is jealous of him and sends him away telling him' (Astypalaia, Dodekanese; DD 56)

A corollary of this analysis is the differential behavior of clitics in initial and noninitial conjuncts. When, for instance, $\Sigma$ Ps are conjoined within a $\mathrm{CP}$ with some lexical 
material in the $\mathrm{C}$ projection, a clitic in the first conjunct finds a host to its left, but clitics in subsequent conjuncts may be forced to prosodically invert. Dawkins 1950 notes just this effect for dialects of the Dodekanese, and we have also found it in his Cappadocian texts.

\section{[16] eména án me batərdóis tría forás, ke vүáliz me so mílu so šifón,} me if me dip three times and take out me the mill the stream

'if you dip me and take me out three times in the millstream, (Silli, Cappadocia; D 308)

The reversion to postverbal clitics in non-initial conjuncts is predicted on the present treatment. The syntactic structure is displayed in [17]; the clitic in the second conjunct undergoes prosodic inversion while the one in the first conjunct encliticizes onto $a$.

$[17]\left[\mathrm{CP}\left[\mathrm{C}^{\prime}\right.\right.$ an $\left.\left.\left.\left[\Sigma \mathrm{P}\left[\Sigma \mathrm{P}\left[\mathrm{TnNP}_{\mathrm{N}} \mathrm{Cl} \mathrm{V} \ldots\right]\right] \mathrm{ke}\left[\Sigma \mathrm{P}\left[\mathrm{TNNP}_{\mathrm{N}} \mathrm{Cl} \mathrm{V} \ldots\right]\right]\right]\right]\right]\right]$

Turning to the other case of adjunction, namely topics, a clitic that immediately follows an argument topic syntactically undergoes prosodic inversion in Type A dialects. [18a] illustrates this; compare with the standard Greek version of the sentence in [18b], where the same NP is also a topic, triggering clitic doubling.

a. [тор Tó líko ] rótsan do $\ldots$ the wolf asked-3pl him

'They asked the wolf ...' (Axos, Cappadocia; M \& K 182)

b. [тор Ton liko ] ton rotisan ....

the wolf him asked-3pl

'They asked the wolf ...' (Modern Greek)

Adjunct topics (such as adverbial modifiers) can adjoin to $\Sigma$ P, with prosodic inversion under exactly the same conditions:

[19] [тор símer to purnó ] [тор pour na paén, ] ekaméndes m éna today the morning before NA leave-3sg made-3sg them with one

lóo t éna spit

word his a house

'This morning, before he left, he made them a house with one word.' (Demirdesi; Dang 176)

In order to justify this analysis, it is important to be able to identify a preposed constituent as a topic. Topics serve certain discourse functions, and non-subject argument topics trigger clitic doubling, as in Standard Modern Greek. Therefore, a clitic related to a topic will appear postverbally if there is no appropriate preverbal material within 
the same CP to host it. The predicted correlation is documented for a range of cases in the examples below. In all of these cases Modern Greek permits preverbal topics as well. [20] illustrates that subsectional anaphors are topics. A clitic immediately following it in the syntax is placed after the verb.

a. Énas patišáhos íhe tría perjá. [тор Ta rjó ] díkisén da. A king had three sons the two married-3sg them 'A king had three sons. Two of them he married off.' (Ghurzono, Cappadocia; D 340)

b. Enas vasiljas ihe tria agorja. [тор Ta dio ] $\underline{\text { ta }}$ pandrepse. a king had three sons the two them married-3sg off 'A king had three sons. Two of them he married off.' (Modern Greek)

[21] illustrates that the same is true for contrastive topics:

a. ekínos píren ti vasilé tin gor ke [тор to rambró ] he took the king the daughter and the bridegroom edosándon tin aorefí $t$ gave-3pl him the sister his 'He married the king's daughter and they married (the would be) bridegroom (of the king's daughter) with his sister.' (Demirdesi; Dang 220)

b. Ekinos pandreftike tin kori tou vasilja ke [тор ton he married the daughter the-Gen king-Gen and the

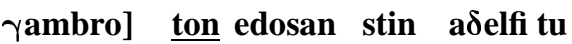
bridegroom him gave-3pl to the sister his 'He married the king's daughter and they married (the would be) bridegroom (of the king's daughter) with his sister.' (Modern Greek)

A topic can also introduce a shift in narrative perspective. If there is no other material between the topic and the clitic, the clitic is again postverbal.

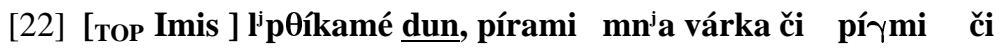
we felt sorry him took- $1 \mathrm{pl}$ a boat and went- $1 \mathrm{pl}$ and pjásamé dun caught-1pl him

'We felt sorry for him, we took a boat and went and saved him.' (Plomari, Lesvos; K 495) 


\section{Type C Dialects: clitics as word-level affixes}

\subsection{The distribution of clitics in $\mathrm{C}$ dialects}

In type $\mathrm{C}$ systems, clitics directly precede the finite verb whose arguments they are. The properties of type $\mathrm{C}$ dialects are well known from SMG. The pattern is illustrated in [23].

a. Tis to ipa.

her-gen it-acc said-1sg

'I said it to her.'

b. Tis to exo pi.

her-gen it-acc have-1sg said

'I've said it to her.'

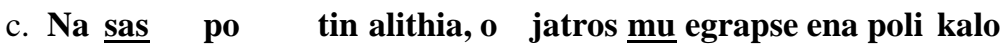
NA you-pl say-1sg the truth the doctor me wrote a very good siropi.

syrup

'To tell you the truth, the doctor wrote me a prescription for a very good syrup.'

d. Mou anikse i miti mja xara.

me-Gen opened the nose one joy

'My nose cleared very well.'

This pattern is widespread in mainland Greece; the examples in [24] and [25] illustrate that the Greek dialects spoken in Italy also conform to it.

[24] Salento (Profili 1999)

a. Na $\underline{\text { sas }}$ po pròbbio to justo, $\mathrm{o}$ mèdekòmmu $\underline{\mathrm{m}} \hat{\mathbf{o}}$ NA you-pl say-1sg truth the real the doctor my me is grammena ena sceruppo ka è ppròbbio kkalò.

written a syrup that is really good

'To tell you the truth, the doctor wrote me a prescription for some syrup which is really good.'

b. Mu svuddhìete e mitti mia bbelletza.

me-Gen discharge the nose one beauty

'My nose is clear, just like that.'

c. Ma quai pràmata 'e mmas eddiaènnane manku atti cciofali. but some things not us pass through even from the head But there were certain things that we would never have thought of.' 
[25] Calabria (Katsoyannou 1999)

a. óde tin ékaman di skóla

here it did-3pl the school

'They went to school here.'

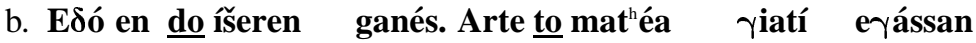
here not it knew-3sg noone now it learned-3pl because left-3pl

óšot $^{\mathrm{h} e}$ če ótu to mattéa

so and thus it learned-3pl

'No-one knew it here. Now they've learned it because they've left (the village) so they learned it that way.'

c. íxen ečínu pu séla na páu ma en dus afínna

had-3sg those that wanted-3pl NA go-3pl but not them let-3pl

'There were some who wanted to go, but they wouldn't let them.'

\subsection{Deriving the distribution of clitics in $\mathrm{C}$ dialects}

We assume that type $\mathrm{C}$ dialects have the clausal structure [3], like type A dialects. There is just one difference: clitics are affixes which subcategorize for a phonological word on their right. Therefore, they do not attach syntactically to TNSP, but lexically to the left of a finite verb. As part of the finite verb, they move with it to $\mathrm{TNS}^{0}$. Importantly, they are word-level affixes (not stem-level affixes, like the subject agreement morphemes of Greek), that is to say, they attach to words, forming larger words.

We are adopting here the following tripartite categorization of affixes, empirically motivated and theoretically justified in Kiparsky (to appear): stem-to-stem affixes, stem-to-word affixes and word-to-word affixes (lexical clitics). These three categories are assumed to be universal, but the allocation of morphemes to them is not predictable and not all languages necessarily have all types of affixes.

That clitics in standard Greek are lexical affixes (albeit not word-to-word affixes) has been argued for by Joseph 1988 on the basis of phonological and morphological evidence. A syntactic argument is that they do not combine lexically with non-finite verbs. It is virtually a definitional property of agreement morphemes that they are affixed only to finite verbs. For example, subject agreement in all Greek dialects is restricted to finite verbs. If object clitics are lexical agreement morphemes, we can understand why they obey this restriction; otherwise it remains unmotivated.

A second argument that clitics are lexical affixes in type $\mathrm{C}$ dialects is that conjoined finite verbs cannot share a clitic. If clitics were syntactically adjoined to a $\mathrm{V}^{0}$ head, then in principle they should be capable of being hosted by a conjoined $\mathrm{V}^{0}$ head (as they in fact are in the dialects where they are $\mathrm{X}^{0}$ categories, such as Pontic and Kozani, see below). Sentences like [26] are, however, ungrammatical in C dialects (in the intended interpretation). 
[26]* to eliose ki exase

it melted and lost

'She melted it and lost it.'

In contrast, sentences like [27] are grammatical, since the auxiliary with the attached clitic has scope over both conjuncts.

\section{[27] Ekino to vra $i$ me ixe vrisi ke xtipisi}

that the evening me had cursed and hit

'That evening he had cursed me and hit me.'

[28] shows the relevant structures of [26] and [27].

[28]

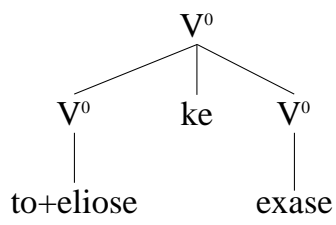

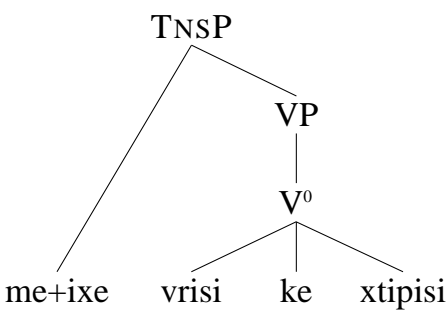

Since we claim that clitics are word-level affixes, adopting the distinction between stem-level and word-level affixes argued for in Kiparsky (to appear), our position is to be distinguished from that of Joseph. Not only are lexical clitics predicted to be on the outside of all inflectional affixes, they are, moreover, predicted to differ from inflectional affixes in their phonological properties. The reason is that stems satisfy the stem phonology, while words satisfy the word phonology. We believe that existing phonological or morphological arguments against the lexical status of clitics in standard Greek, such as those in Philippaki-Warburton \& Spyropoulos (1999), are arguments against the analysis of clitics as stem-level affixes, rather than as word-level affixes.

\section{Type B Dialects: Syntactic $X^{0}$ Clitics}

\subsection{Pontic clitics are always postverbal}

In the majority of Pontic dialects, the placement of clitics is easily stated: clitics are always postverbal (Papadopoulos 1955, Oikonomidis 1958, Černyševa 1958, Drettas 1997), even in environments where they are preverbal in the other dialects (see section 2.3): $:^{17}$ 


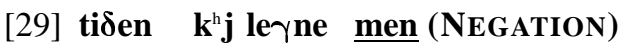

nothing not tell-3pl me

'They tell me nothing at all.' (Dr 632)

a. as akugna ta ek deftern (MOOD PARTICLE)

AS hear it from second time

'Let us hear it a second time.' (Dr 632)

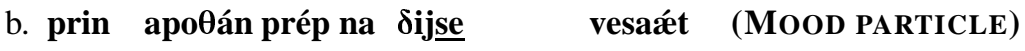

before dies must NA give-3Sg you testament

'Before he dies, he must give you his testament.' (Dr 380)

[31] ondas telion ato (COMPLEMENTIZER)

when finish-1sg it

'when I finish it' (Trapezounda; P 224)

[32] do les me (Wh-INTERROGATIVE)

what tell-2sg me

'What are you telling me?' (P 159)

[33] ekino [Foc eyo ] exer ato (Focus)

that I know it

'Only I know that.' (Trapezounda; P 224)

The Ophitic dialects spoken by the Pontic Moslems (Mackridge 1987, 1999) represent the same kind of system:

[34] a. Polá na xarénumes alomíjan an elépume sas. much subj be-glad another-time if see you

'We shall we very glad if we see you again.'

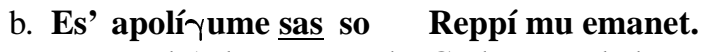
you send-1Pl you to-the God as pledge 'We're sending you as a pledge to God.'

\subsection{Pontic clitics are not suffixes but $\mathrm{X}^{0}$ enclitics}

Clearly, Pontic clitics are enclitic rather than proclitic. However, they differ from both type $\mathrm{A}$ and type $\mathrm{C}$ clitics in a subtler way. It would be tempting to see Pontic as the mirror image of SMG, and indeed Drettas 1997 claims that they are object agreement suffixes (see also Janse 1998). We think that Pontic clitics require a syntactic analysis. Our proposal is that they are phonologically enclitic (just as in type A dialects), but 
that they are of category $\mathrm{X}^{0}$ rather than of category $\mathrm{X}^{\max }$. Consequently, they are head-adjoined to $\mathrm{V}^{0}$, rather than adjoined to a phrasal functional projection, and their syntax differs from that of Type A clitics accordingly. The $\mathrm{X}^{0}$ status of Pontic clitics is supported by the following three arguments.

First, in the perfect, clitics in Pontic are attached to the infinitive, not to the auxiliary:

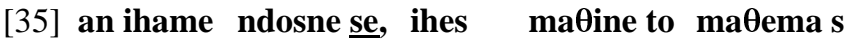

if had-1pl beaten you had-2sg learned the lesson yours

'If we had beaten you, you would have learned your lesson.' (Trapezounda; P 174)

Since lexical agreement affixes (morphological argument clitics) go only on finite verbs (section 3.2), this shows that clitics are not agreement affixes.

Secondly, conjoined verbs may share a single clitic, which then always appears to their right.

[36] a. esegen to vutoron $s$ son furnin $k$ elisen $k$ exasen a. put-3sg the butter in the oven and melted and lost it 'She put the butter in the oven and melted it and lost it.' (Adissa Argiroupoleos; P 200)

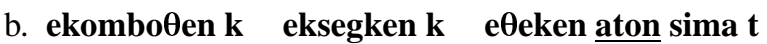
was duped and took out and put her near him 'He was duped and took her out and put her near him.' (Trapezounda; $\mathrm{P}$ 22)

c. Ekínos pa epróstaksen na lúzne ke plín aten he PA ordered subj shampoo and wash him 'He ordered them to shampoo him and to wash him.' (Imera, Fostiropoulou 1938:190)

This sharply contrasts with standard Greek, where the clitic is obligatorily repeated in such cases, as would be expected for an affix. ${ }^{18}$ The behavior of clitics in conjunction thus confirms that they are lexical in standard Greek and syntactic in Pontic.

The third argument comes from phonology, which shows that clitics are not part of the same lexical word as their hosts (though they are surely part of the same postlexical word). The argument is based on a stress contrast between simple long words and words with attached clitics. In simple long words, when the lexical stress is before the antepenult syllable, rhythmic alternating stresses are assigned to the word (e.g., éklapsa, éklapsáne, ekimúmunéstine). However, no such additional stresses appear in clitic sequences, as explicitly stated by Papadopoulos 1955:32. If clitics were lexical suffixes, this difference would be unmotivated. 
In support of his claim that Pontic clitics are affixes, Drettas 1997 argues that they combine with their hosts in phonologically idiosyncratic ways. Drettas' principal argument is that the third person object forms fáisen, fázaton in [37] cannot be derived by phonological rules. ${ }^{19}$

$\begin{array}{llll} & & \text { 'you' (Sg.) } & \text { 'him' } \\ 1 \mathrm{Sg} . & \text { fázo } & \text { fázosen } & \text { fázaton } \\ 2 \mathrm{Sg} & \text { fáis } & & \\ 3 \mathrm{Sg} & \text { fáz } & \text { fáisen } & \text { fáisaton } \\ \text { fázaxton }\end{array}$

In order to assess this argument, consider first the paradigms of the simple verbs fazo 'feed', pleko 'knit', siro 'drag', and vrexo 'rain' in Pontic.

$\begin{array}{llllll} & & \text { /faz-/ } & \text { /plek-/ } & \text { /sir-/ } & \text { /vrex-/ } \\ \text { 1.sg. } & \text { /-o/ } & \text { fázo } & \text { pléko } & \text { síro } & \text { vréxo } \\ \text { 2.sg. } & \text { /-is/ } & \text { fáis } & \text { pléks } & \text { sírts } & \text { vréis } \\ \text { 3.sg. } & \text { /-i/ } & \text { fáz } & \text { plék } & \text { sír } & \text { vréš } \\ \text { 1.pl. } & \text { /-omen/ } & \text { fázomen } & \text { plékomen } & \text { síromen } & \text { vréxomen } \\ \text { 2.pl. } & \text { /-eten/ } & \text { fázeten } & \text { pléketen } & \text { síreten } & \text { vréšeten } \\ \text { 3.pl. } & \text { /-ne/ } & \text { fázne } & \text { plékne } & \text { sírne } & \text { vréxne }\end{array}$

Regular phonological processes of Pontic account for these inflectional patterns. The alternation of $x$ and š in vréxo, vréxomen, vréxne versus vréšeten is due to palatalization of $x$ to $\check{s}$ before a front vowel. The same palatalization process also accounts for 3.Sg. vréš. Apocope of final $i$ is a productive phonological process in Pontic. It is motivated by such contrasts as /podári/ podár 'foot' versus /podári-mu/ podárim 'my foot', with retention of non-final $-i$ in the latter form. The process seems to be automatic, in that no phonological phrase or phonological word can end in $-i$. Thus, we posit the third person ending as /-i/, which triggers palatalization in /vréx-i/ $\rightarrow$ vréši, and is obligatorily apocopated.

The same regular phonological processes apply to clitic combinations as well. The phonological derivations are as follows.

$\begin{array}{llll}\text { [39] } 1 \mathrm{Sg} . & \text { /fáz-o/ } & \rightarrow \text { fázosen } \\ 2 \mathrm{Sg} . & \text { /fáz-is/ } & \rightarrow \text { fáis } \\ \text { 3Sg. } & \text { /fáz-i/ } & \rightarrow \text { fáz } \\ \text { 1Sg.2Sg. } & \text { /fáz-o-sen/ } & \rightarrow \text { fázosen } \\ \text { 1Sg.3Sg. } & \text { /fáz-o-aton/ } & \rightarrow \text { fázaton } \\ \text { 2Sg.3Sg. } & \text { /fáz-is-aton/ } & \rightarrow \text { fáisaton } \\ \text { 3Sg.2Sg. } & \text { /fáz-i-sen/ } & \rightarrow \text { fáisen } \\ \text { 3Sg.3Sg. } & \text { /fáz-i-aton/ } & \rightarrow \text { fázaton }\end{array}$

These derivations require only independently motivated general phonological processes of Pontic. The realization of $2 \mathrm{Sg}$. /fáz-is/ as fáis, and $3 \mathrm{Sg} .+2 \mathrm{Sg}$. /faz-i-sen/ 
as faisen is due to a regular process of Pontic, widespread in other Northern Greek dialects as well. Apparently without exception, the sequences /-Vsis-/ and /-Vzis-/ are realized as -Vis- in Pontic. A plausible derivation is /fáz-is/ $\rightarrow$ fážis $\rightarrow$ fážs $\rightarrow$ fáis (Malikouti-Drachman and Drachman 1977, Fatima Eloeva, p.c.). ${ }^{20}$ This process (“anameiosis", Oikonomides 1937, Papadopoulos 1955:13,26) applies even in underived lexical items, such as the names Anastasis $\rightarrow$ Anastais, kurnazis $\rightarrow$ kurnais, Karagiozis $\rightarrow$ Karagöis, and similarly Thanais, Thodois, Kondofois, etc. It is fed by the previously described palatalization of /x/ before /i/, e.g., /vréx-is/vréis (cf. vréxo).

3Sg.+3Sg. /faz-i-aton/ $\rightarrow$ fázacton is derived by vowel contraction (synalepha) $/ \mathrm{i}, \mathrm{e}+\mathrm{a} / \rightarrow \ddot{a}, / \mathrm{i}, \mathrm{e}+\mathrm{O} / \rightarrow \ddot{o}$. This is also an automatic postlexical phonological process in Pontic, which applies across word boundaries as well, as Papadopoulos 1955:11 makes clear. ${ }^{21}$ For example: mi a yapás aton $\rightarrow$ mä yapás aton, érxume ontáman $\rightarrow$ érxum öntáman.

Finally, $1 \mathrm{Sg} .+3 \mathrm{Sg}$. /fazo-aton/ $\rightarrow$ fázaton is a straightforward case of elision of a vowel before another vowel, also a process which applies regularly in Pontic, within and across words. ${ }^{22}$

We conclude that verb + clitic combinations are derived by phonological processes which apply within words and across word boundaries, and which are exceptionless, as far as the evidence shows. If so, the phonology of Pontic clitics is consistent with $\mathrm{X}^{0}$ cliticization, and Drettas' argument for their affixal status does not go through.

\section{The diachronic perspective}

\subsection{The lexicalization trajectory}

The generalization that syntactic combinations tend to become grammaticalized (or reanalyzed) as lexical, but not conversely, implies that the three dialects are historically related as follows:

$$
\text { System A } \underset{X^{\max } \rightarrow X^{0}}{\longrightarrow} \text { System B } \underset{X^{0} \rightarrow \text { Affix }}{\longrightarrow} \text { System C }
$$

Accordingly, the system of the A-type dialects must be the most archaic of the three. The dialectological picture itself suggests this because A-dialects are peripheral in the Greek-speaking area. More compelling is the fact that some A-dialects occur as enclaves within B- and C-dialects, as on Lesbos, presumably as relics of an earlier wider distribution of the A type. But perhaps the most telling fact is that the syntax of A-dialects is closest to the medieval Greek system, as sketched out in Mackridge (1993). We show this directly below, in section 5.2. 
Based on these considerations we posit the starting point as an A-type dialect, that is, a dialect with $\mathrm{X}^{\max }$ clitics. These $\mathrm{X}^{\max }$ clitics developed into $\mathrm{X}^{0}$ clitics in Pontic, and further became lexical clitics in Western Greek.

However, if this were simply a direct development as in [40], we would have no explanation for why Pontic developed enclitics and Western Greek developed proclitics. It is more likely that the two systems sprang from earlier systems with $\mathrm{X}^{\max }$ clitics which already differed syntactically, in such a way that "Proto-Pontic" had predominantly postverbal clitics (which were lexicalized as $\mathrm{X}^{0}$ enclitics in modern Pontic), and "proto-Western Greek" had predominantly preverbal clitics (which developed into the type $\mathrm{C}$ proclitics). In the following sections we attempt to trace these respective paths of development.

\subsection{Medieval Greek}

According to the excellent description of Mackridge 1993, the position of clitics in late medieval Greek (12th to 16th centuries) is governed as follows:

[41] a. The order $\mathrm{V}+\mathrm{Cl}$ is more or less obligatory:

1. when the verb stands at the beginning of the clause or immediately follows a coordinating conjunction.

2. when the verb comes immediately after one of the following:

$$
\begin{aligned}
& \text { the complementizer oti } \\
& \text { the causal conjunction } \delta i o t i \\
& \text { the conditional conjunction } e i \\
& \text { the negative adverb ou }
\end{aligned}
$$

3. when the verb is preceded by an object with the same referent as that of the clitic (i.e., when the clitic is resumptive or doubling).

b. The order $\mathrm{Cl}+\mathrm{V}$ is more or less obligatory when the verb comes immediately after one of the following:

the final conjunction ina

the particles $n a$, as, $\theta a$

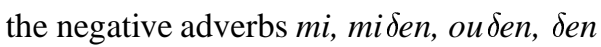

all interrogatives pronouns and adverbs

the complementizer pos

all temporal and comparative conjunctions

the conditional conjunctions an, ean

all relative pronouns

c. The order $\mathrm{Cl}+\mathrm{V}$ is almost obligatory when some semantically emphasized word or phrase precedes the verb. 
$\mathrm{d}$. The order $\mathrm{Cl}+\mathrm{V}$ is normal when the subject precedes the verb.

e. The position of the clitic before or after the verb is relatively free when a temporal adverb precedes the verb.

f. A coordinating conjunction such as $k e$ removes the force of a preceding subordinating conjunction, thus restoring the order $\mathrm{V}+\mathrm{Cl}$.

From Mackridge's formulation in [41] it will be seen that the system is basically a type A dialect with some extra wrinkles. ${ }^{23}$ We take up the cases in turn.

Cases (a1) and (a3) are straightforward (section 2.4). With respect to case (a3), Pappas 2001:102 makes an additional observation: with respect to a topicalized object with clitic doubling, "the adjective olos ['all'] behaves contrary to the general pattern [postverbal clitics], since one finds pronouns in the preverbal position when olos is the doubled element."

\section{[42] tes xores mu olo $i$ ira oles tes afanizi}

the countries my all-around all them destroy

'My countries all around, he destroys them all.' (Pappas p. 79)

Here tes xores mu oloyira is the topic adjoined to $\Sigma \mathrm{P}$, and oles is a focused floated quantifier in $[\mathrm{Spec}, \Sigma \mathrm{P}]$. The preverbal positioning of the clitic, then, is predicted by our analysis.

Turning to (b) and (c) in [41], we see that complementizers, wh-elements, negation, modal particles, and preposed focus XPs host clitics, which then are preverbal, as in Type A dialects (section 2.3). What is surprising in [41] is the contrast between the complementizers and the negation in (a2) and those in (b). It may tentatively be interpreted as follows.

The conjunctions oti, dioti... in [41a2] are old relative pronouns (as Horrocks 1997 points out). It is reasonable to assume that they are still in [Spec,CP] at this point, and trigger V-to-C movement. (Pappas 2001 shows that in the more extensive material examined by him, dioti has become regularized to occur with preverbal Clitics.) The negation ou also triggers V-to-C movement. ${ }^{24}$ Mackridge 1993 also notes a residual case of material in $[\mathrm{Spec}, \mathrm{CP}]$ triggering V-to-C movement in early Medieval Greek.

[43] to pos ikokirevo mou tin apasan ikian the how manage household my the entire home

'how I manage my entire household'

The structure of [43] is presumably: $:^{25}$

[44] [CP pos [C, ikokirevo [TnsP $\mathrm{Cl} \ldots]]]$ 
In the modern type A dialects, these items have been largely regularized. However, the dialect of Pharasa has preserved a cognate of the negation ou, in the form $\check{\text { jo, which }}$ retains the old syntactic behavior (Dawkins 1916). As for the conditional complementizer $e i$, Pappas 2001 notes that it is almost always followed by the contrastive particle $\delta$ e, which perhaps introduced an intonation break.

The variation in (d) and (e), confirmed in Pappas' study, can be attributed to structural ambiguity. Preverbal subjects (case (d)) fall both under case (c) (focus in $[$ Spec, $\Sigma \mathrm{P}]$ ), and under case (a3) (topic adjoined to $\Sigma \mathrm{P}$ ), except that subjects do not trigger clitic doubling, as in all Greek dialects. In texts, the ambiguity can sometimes be resolved, however, when the discourse status of a preverbal subject is established by context. In any case, preverbal subjects would host a clitic if they are in the specifier position of a functional projection, and not if they are adjoined.

The variation in case (e) is slightly different. Certain one-word temporal adverbs are simply $\mathrm{X}^{0}$, and these can be within the $\Sigma$ projection. Phrasal adverbs, on the other hand, would be adjoined. Evidence for the $\mathrm{X}^{0}$ status of certain temporal adverbs in Standard Modern Greek is that they can intervene between a focus or a wh-phrase and the verb (Alexiadou 1994):

[45] a. Pjon akoma skeftete o Yanis?

Who-acc still thinks the John-nom

'Who is John still thinking about?'

b. Pjo arthro idhi ehi teliosi o Yanis?

which article has already finished the John-nom

'Which article has John already finished?'

a. Ti MARIA akoma skeftete o Yanis.

the Mary-acc still think-3sg John-nom

'John is still thinking about MARY.'

b. To ARTHRO idhi ehi teliosi o Yanis.

the article already has finished the John

'John has already finished the ARTICLE.'

The adverbs identified by Mackridge as falling under (e) in late medieval Greek form a larger class than the $X^{0}$ temporal adverbials in SMG; nevertheless it is suggestive that they are all one-word temporal adverbs, such as panta 'always', tote 'then', palin 'again', ef $\theta i s$ 'immediately'.

Finally, the non-parallelism of conjuncts in (f), illustrated in [47], is due to coordination of internal $\Sigma$ Ps, already demonstrated for type A dialects in section [2.4].

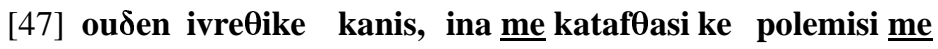
neither was found anyone to me reach and fight me 'neither has there been anyone to challenge me and fight me' (Digenis Akritas, Escorial version 100) 
As noted earlier, this so far unexplained peculiarity, recorded in Mackridge 1993 and in Pappas 2001, finds an explanation in our account. The crucial point is that the generalization about clitic order is not to be framed in terms of main clauses versus subordinate clauses but in terms of the concomitant structures.

\subsection{Pontic}

In section 5.1 we reasoned that Pontic must be descended from a dialect in which clitics were predominantly postverbal. In fact, a dialect with the hypothesized "protoPontic" properties is already implicit in our historical analysis. It may be identified with a stage of Greek prior to the emergence of $\Sigma$, where TNSP was the highest IP projection, and the finite verb moved to $\mathrm{C}$ (recall the residual V-to-C movement of section 5.2). At this stage, clitics were at the left edge of IP, and the verb could be to their left. This dialect would have had the phrase structure in [48].

[48]

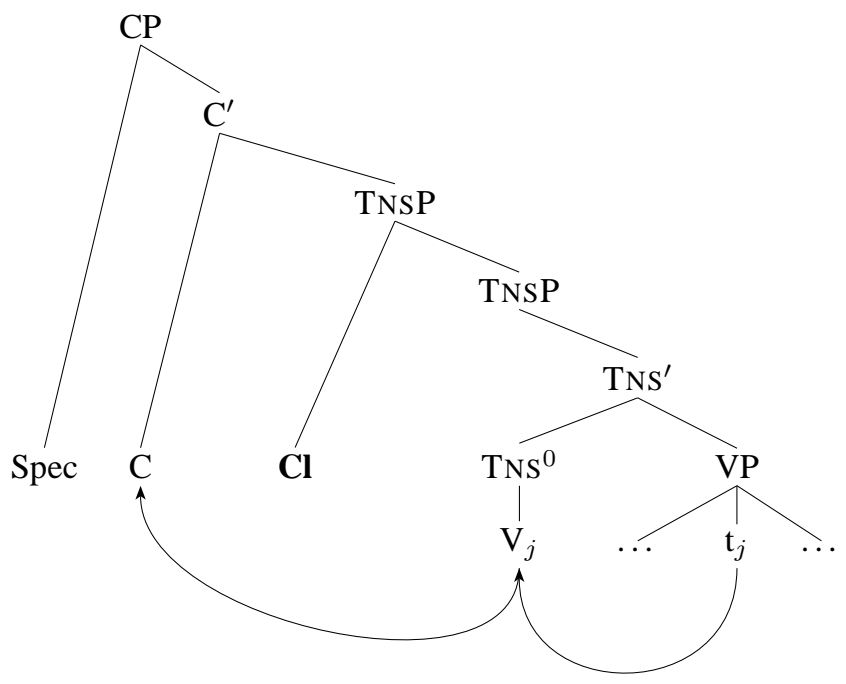

At the stage before $\Sigma \mathrm{P}$ was introduced, focused elements and negation would have been fronted to Spec-CP. Movement of the verb to $\mathrm{C}$ in such cases would then have resulted in postverbal positioning of clitics. There is good evidence that such clitic positioning began to arise, as an option to inherited Wackernagel cliticization, during the classical Greek period, as illustrated by the following examples from Herodotus (cited from Garrett 1995).

a. tỗn mèn dè oudèn prosíetó min they-GenPI FOCUS Prt NEG attracted him

'Not one of them attracted him.' (Hdt. 2.68.48) 
b. ek toútou dè manễnai min nomízousi Spartiễtai from this FOCUS go-mad him-Acc think-3Pl Spartans

'It's from this that the Spartans think he went mad.' (Hdt. 6.84.3)

c. póthen an láboimi rhễma muriámphoron hótōi

where Prt take-Opt-1Sg word myriad-measures-holding which-DatSg

proséipō $\underline{\text { s' }}$

address-Sbj-1Sg you-Acc

'Where can I find a zillion-dollar word with which to address you?' (Ar.

Pax 521-22)

Our hypothesis predicts that the medieval Pontic system should display robust evidence of this syntax. Indeed, in deeds to the monastery of Vazelon (south of Trebizond), we find examples like the following:

[50] Medieval Pontic (Ouspensky and Bénéchevitch 1927)

a. ton de tópon edốkamén soi eis toùs eksễs kaì diēnekeĩs xrónous the Prt place we gave you in the following and everlasting years

'we have given you this land in perpetuity' (deed dated 1260)

b. hoson diaphérei mou

how much belongs me-Dat

'as much as is my share' (dated 1435)

[50b] is especially interesting because it shows a postverbal clitic in the presence of a wh-element, differing from the late medieval system discussed in section 5.2. Another characteristic Pontic trait seen in these early texts is multiple preposed negation.

\section{[51] tinán típote ou xreostó}

nobody nothing not owe- $1 \mathrm{Sg}$

'I don't owe anyone anything' (ibid., dated 1291)

In a system such as [48] where $\mathrm{V}$ raises to $\mathrm{C}$ in main clauses, the majority of clitics will end up in postverbal position. In such dialects, lexicalization from $\mathrm{X}^{\max }$ to $\mathrm{X}^{0}$ would naturally give rise to enclitics, as in Pontic.

After the Pontic dialects diverged at an early stage of Medieval Greek, the other Greek dialects underwent a period of further common development (which included the rise of $\Sigma \mathrm{P}$ ) before in turn splitting off into the ancestors of the Cappadocian dialects (type A) and the Western Greek dialects (type C). 


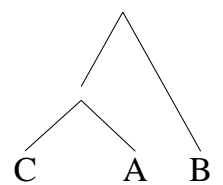

The implication that the Pontic (type B) dialects split off from the rest of Greek quite early, and that type $\mathrm{A}$ and type $\mathrm{C}$ dialects underwent a period of common development, is consistent with Dawkins' 1940 suggestion that the Pontic dialects were separated from the rest of Greek as early as the 11th century by the Seljuk conquests, several centuries before the rest of Asia Minor's Greek dialects (including those of Cappadocia) were cut off by the Ottoman incursion.

\subsection{Kozani: the missing link}

If we adopt the view that syntactic change takes place by small stepwise increments rather than by Lightfootian catastrophes, we must assume that Western Greek did not develop directly from a type A system where clitics are $\mathrm{X}^{\max }$ categories, but passed through an intermediate Pontic-type stage of syntactic $X^{0}$ cliticization. In fact, we are led to posit as the immediate antecedent of standard/Western Greek a system B', where clitics already precede the verb, but still retain their syntactic $\mathrm{X}^{0}$ status, like the Pontic clitics. This system would constitute the mirror image of Pontic:

[53]

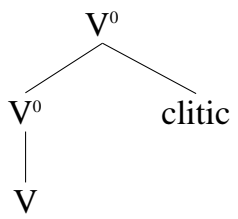

System B (Pontic)

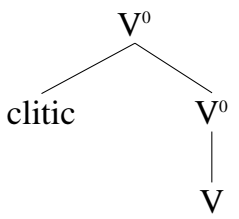

System $B^{\prime}$ (inferred)

We shall now argue that system $\mathrm{B}^{\prime}$ survives to this day.

Kontosopoulos 1994:53,101 reports that clitics are placed between the auxiliary and the participle in two modern dialects: Kozani (Macedonia) and Chios (off the coast of Asia Minor).

a. íxan ts $\underline{\text { vaps }}$ (Kozani) had-3Pl them painted 'they had painted them'

b. íxen me piási (Chios) has-3Sg me caught 'he has caught me'

tus íxan vápsi (Standard Greek)

me íxe piási (Standard Greek) 
The hypothesis that these dialects instantiate our predicted "missing link" between between types $\mathrm{A}$ and $\mathrm{B}$, that is, $\mathrm{X}^{0}$ proclitics makes several syntactic and phonological predictions. Kiparsky et al. (2001) were able to confirm these predictions by interviewing a speaker of the dialect.

Kiparsky et al. found that in the Kozani dialect clitics may be placed either before the auxiliary, or, as Kontosopoulos reports, between it and the main verb. This seems to be a genuine option within the dialect itself. The repetition of the clitic in [55b] shows that the clitic in [54a] and in [55a] must attach to $\mathrm{V}^{0}$, rather than to the auxiliary.

a. íxan ts vaps ki ftiaks had-3Pl them painted and fixed 'they had painted and fixed them' (preferred)

b. íxan ts vaps ki ts ftiaks had-3Pl them painted and them fixed 'they had painted them and fixed them'

Our first syntactic prediction is that conjoined verbs may share an $\mathrm{X}^{0}$ clitic, as in Pontic. Specifically, whereas Pontic's shared enclitics always follow the verb conjunction (see [36]), in Kozani we expected that its shared proclitics would precede it. This is what we find; see [56]. [56a] (though ungrammatical in standard Greek) is in fact preferred over [56c].

a. $\underline{\mathbf{n}}$ ída ke xerétsa her saw-1Sg and greeted-1Sg

'I saw her and greeted her'

b.*ída ke $\underline{\mathbf{t}}$ xerétsa

'saw-1Sg and her greeted-1Sg

'I saw and greeted her'

c. $\underline{\mathbf{n}}$ ída ke $\underline{\mathbf{t}}$ xerétsa

her saw-1Sg and her greeted-1Sg

'I saw her and greeted her'

The respective structures for Pontic and Kozani are given in [57].

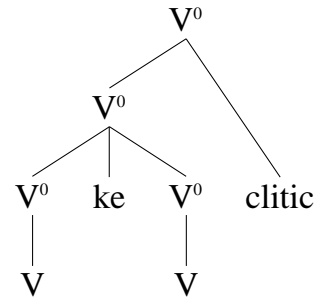

Pontic

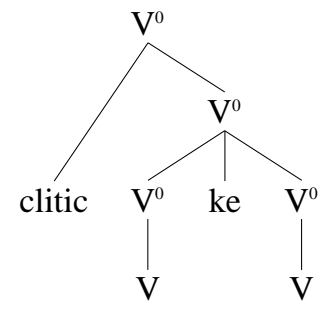

Kozani 
A second syntactic consequence is that VP-adverbs may intervene between the auxiliary and the clitic, but nothing may intervene between the clitic and the following nonfinite verb.
a. íxan keró ts vaps had-3Pl already them painted 'they had already painted them'
b.*íxan ts keró vaps had-3Pl them already painted 'they had already painted them'

This follows on the plausible assumption that VP-adverbs are at the left edge of VP, and that the VP is the complement of the auxiliary.

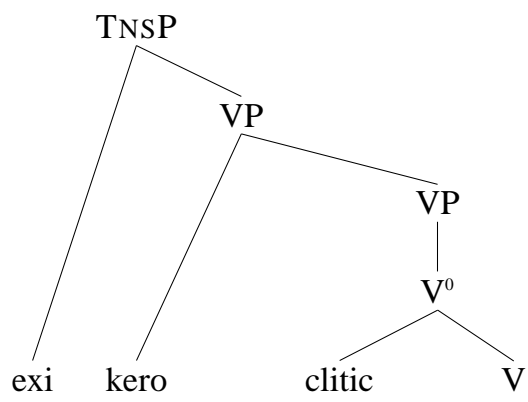

Kiparsky et al. also give two phonological arguments that the clitic is a proclitic on the participle rather than an enclitic on the finite auxiliary. One comes from stress. In verb forms which bear lexical stress before the antepenult, a second, equally prominent stress is assigned to the penult, in order to avoid a stress lapse, as in [60a]. No such stress is assigned in cases like [60b].

a. éfagámi

'ate-1Pl'

'we ate'

b. íxame to vaps (not *íxamé to vaps)

had-1Pl it painted

'we had painted it'

The reason is that in [60b], the sequence ixame to is not a word either lexically or postlexically, according to our analysis. Therefore, it cannot be assigned word stress at any level of the phonology.

The second phonological argument comes from a process of voicing assimilation of [s] to [z] before [m] within prosodic words ${ }^{26}$ The final [-s] of a verb does not voice before an object clitic beginning with [m-], which shows that there is no enclisis. 
[61] /exis mas $\delta \mathrm{i} / \rightarrow$ [exis maz $\delta \mathrm{i}]$ 'you've seen us'

The Kozani dialect also has enclitic pronouns, such as possessive clitics. These seem to have the status of lexical suffixes, just as in standard Greek.

$[62] / \delta$ ikos mas $/ \rightarrow[\theta$ kozmas] 'our own'

The object proclitics of Kozani, then, confirm the hypothesized $\mathrm{B}^{\prime}$ system. It remains to be seen how widespread it is, and in particular whether the Chios dialect is similar to that of Kozani.

More importantly, our prediction that the $\mathrm{B}^{\prime}$ system is the immediate antecedent of the standard/Western Greek $C$ system remains to be verified by historical data from earlier stages of Greek. ${ }^{27}$

\subsection{Summary of the historical development}

Although we will not attempt to reconstruct the evolution from the two medieval systems back to the Homeric language in this paper, we can offer some preliminary suggestions based on the reinterpretation of Taylor 1994 proposed by Kiparsky 1996. In Homeric Greek, we suppose that no IP (whether TNSP or $\Sigma \mathrm{P}$ ) is syntactically projected. Consequently, $\mathrm{X}^{\max }$ clitics at that stage are adjoined to $\mathrm{CP}$, where they undergo prosodic inversion if necessary to satisfy their enclisis requirement. This is to say that Homeric clitics are second position (Wackernagel) clitics.

In later classical Greek, a syntactic IP (specifically a TNSP, we assume) is introduced. Clitics (still of the $\mathrm{X}^{\max }$ type) adjoin to this lower projection, while finite verbs may move to C. This is the "proto-Pontic" system, in which clitics are predominantly postverbal. Pontic develops from it by the first stage of lexicalization of $\mathrm{X}^{\max }$ clitics, by which they became $\mathrm{X}^{0}$ clitics, with enclitic status.

The dialects from which Western Greek arose developed a $\Sigma \mathrm{P}$ projection, while still at the $\mathrm{X}^{\max }$ stage. This stage is attested in medieval Greek, and persists in the modern Type A dialects. From this starting point, lexicalization of $\mathrm{X}^{\max }$ clitics resulted in a Type $\mathrm{B}^{\prime}$, such as still attested in Kozani. The second stage of lexicalization, by which clitics became affixes, then resulted in the Type $\mathrm{C}$ systems of standard and Western Greek.

This scenario is summarized in the following syntactic stemma of Greek dialects. 


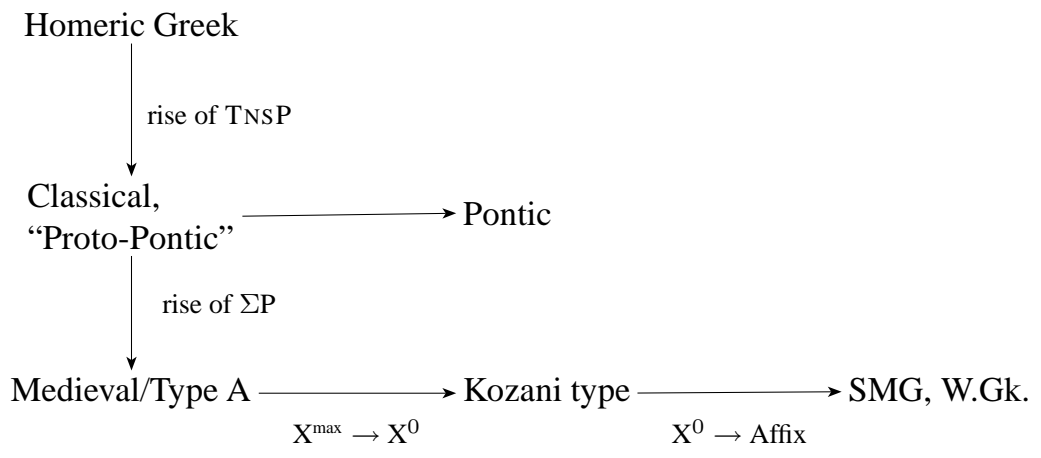

Two corollaries of our analysis of clitic positioning are worth stressing. First, joined with our assumption that syntactic change proceeds in minimal steps, we predict that syntactic variation in clitic positioning, in so far as it reflects ongoing change, should be between systems which are adjacent in the above schema. The variation in Kozani between $\mathrm{X}^{0}$ and affixal cliticization is an example. Dialect mixture or borrowing, on the other hand, could result in variation between any systems. In fact, for one of the two heterogeneous dialects we have found, that of Amisos, which shows variation between Type A and Type B, the predicted dialect mixture is a matter of historical fact. Spoken in the Pontic (type B) area, Amisos is known to have had an influx of refugees from Cappadocian Caesarea (who would have spoken a type A dialect) after the fall of Constantinople in 1453 (Christopoulos 1974:179a).

A second corollary is that the clitics might become (or might already have become) affixal in some dialect of Pontic. Such an innovative dialect of Pontic would have the following characteristics:

[64] Hypothetical $C^{\prime}$ dialect:

a. Clitics are postverbal (as in Pontic): exi ta 'he has them'

b. Clitics attach to finite verbs only (unlike Pontic): exi to kani 'he has done it'

c. Clitics must be repeated in each conjoined verb (unlike Pontic): *na fero ke trog' ' $\underline{a}$ 'I'll take and eat it'

d. Verb+clitic combinations are stressed like lexical words (unlike Pontic): *ésiren atona 'he threw him'

e. Verb+clitic combinations may show lexical idiosyncrasies (unlike Pontic).

\subsection{Implications}

The dialect evidence shows that the distinction between affixal and $\mathrm{X}^{0}$ clitics is minimal and irreducible. On the one hand, we found no intermediate systems to support 
Janse's claim (1998) that the distinction between clitics and affixes is a gradient one. On the other hand, Halpern and Fontana's two-way classification of clitics, which identifies $X^{0}$ clitics with affixes, is not fine-grained enough, and should be replaced by a ternary one. Standard Greek clitics are lexical (as Joseph proposed), but Pontic clitics are syntactic $\mathrm{X}^{0}$ (contra Drettas 1997).

On the historical side, our findings suggest that change is neither catastrophic (as Lightfoot claims) nor gradient (as was suggested in some early work on grammaticalization). Rather, change proceeds in minimal discrete increments. Moreover, it is striking that none of the changes that our theory posits leads to abrupt discontinuities in the output. Each step in the reanalysis or grammaticalization process modifies the language in ways that are not salient to language learners (not to speak of dialectologists).

The recognition of a three-way distinction in clitics, coupled with our view that syntactic change proceeds in minimal steps, led us to predict the existence of system $\mathrm{B}^{\prime}$, the proclitic counterpart of Pontic. Our discovery that the predicted system exists in the dialect of Kozani confirms both assumptions. 


\section{Notes}

${ }^{1}$ This material was presented at the first international conference on modern Greek dialects and linguistic theory at the University of Patras in Oct. 2000, at Stanford University in Nov. 2000, and at the conference on historical morphosyntax at the University of Konstanz in June 2001. We are grateful to the conference organizers, Angela Ralli and Aditi Lahiri, and to the audiences for their suggestions and challenges. For valuable discussion and criticism we are indebted to Andrew Garrett, who, in addition, generously shared his unpublished handouts with us. Comments on previous written versions by Tracy King, Ela Harrison Widdows, an anonymous reviewer, and an editor of this journal, have also greatly improved this paper. Panayiotis Pappas kindly sent us a copy of his unpublished dissertation (2001). It reached us after our paper was substantially written, but we have been able to take some of his most relevant findings into account; we hope to continue the dialogue on another occasion.

${ }^{2}$ Interestingly, a similar trajectory, albeit with two stages, has been proposed for the clitics in some Romance and Slavic languages (Fontana 1993, Tomic 2000).

${ }^{3}$ Of course affixes are sometimes "upgraded" to clitics. In the cases we have examined, this happens by analogy with existing clitic patterns. If this is generally true of upgrading, we would conclude that it differs from grammaticalization, which, as is well known, does not require existing models, and may introduce new categories and structures. In general, the unidirectionality hypothesis should be seen as conceptually similar to the hypothesis that sound change is exceptionless. Both are falsifiable only in the context of an entire theory of change, not simply by unanalyzed instances of change.

${ }^{4}$ The list does not include dialects of which we have read no texts, notably those of Crete, Cyprus, and Rhodes. Judging from published descriptions, these dialects seem to belong in our type A category.

${ }^{5}$ An editor of the journal (citing an unpublished paper by Mackridge which we

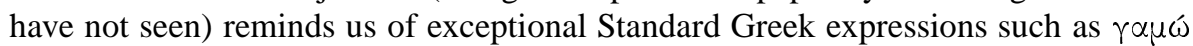
$\sigma \varepsilon$ 'fuck you', $\pi \alpha \tau \varepsilon i \varsigma, \mu \varepsilon, \pi \alpha \tau \omega$ ' $\sigma \varepsilon$ 'pell-mell, a scrum' (lit. 'you step on me, I step on you'). Though idiomatic, with the verbs not constituting clausal heads, these expressions are presumably still parsable into recognizable parts. The exceptional word order is a fixed property of the idioms themselves, and not of any particular clitic.

${ }^{6}$ Dawkins 1950 noted that parts of the Dodekanese show a mix of type A and type $\mathrm{C}$ behavior. We have found another mixed system, that of the dialect of Amisos, formerly spoken in Turkey, which shows variation between type A and B (the Pontic variety). Even in these dialects, the clitics behave uniformly in that all, regardless of their grammatical features, show the same syntactic variation. Our analysis predicts that they represent dialect mixture due to contact and/or to migration (and not endogenous change in progress). See section 5.5. 
${ }^{7}$ A note on the terminology of this paper: by CLITICS we mean elements which are added to words (as opposed to stems). By AFFIXES we mean elements which are added in the lexicon (rather than in the syntax). Thus, the categories of clitics and affixes are not mutually exclusive. For example, the clitics of Standard Modern Greek are affixes, according to what we propose below.

${ }^{8}$ For preverbal focus in SMG see Tsimpli 1995. For emphatic negative elements see Veloudis 1982, Giannakidou 1998, and Tsimpli \& Roussou 1996.

${ }^{9}$ See, e.g., Anagnostopoulou 1994 on clitic doubling in SMG.

${ }^{10}$ Like other approaches which have multiple IP projections and which do not posit verb movement past $\mathrm{TNS}^{0}$, we owe an account of why the specifier position of certain such projections remains unfilled. Alexiadou and Anagnostopoulou 1998 argue that these specifier positions are not licensed in null subject languages, such as Greek.

${ }^{11}$ In fact, our analysis is consistent with an expansion of $\Sigma \mathrm{P}$ into FocP, MoodP, NegP, etc., provided that only the specifier position of FocP may be filled.

${ }^{12}$ This appears to be a pervasive generalization governing clitics in need of a theoretical justification.

${ }^{13}$ This corresponds to the first clause of Halpern's formulation. Halpern also includes a second clause which deals with nondirectional clitics, absent in Greek, according to our analysis.

${ }^{14}$ The distribution of clitics in type A dialects is similar to that of Bulgarian. King 1996 has proposed an analysis of the latter that makes use of prosodic inversion as well.

${ }^{15}$ Another account based on verb movement is that of Philippaki-Warburton 1995. Clitics are adjoined to TNSP, as in our analysis, but the verb moves from $\mathrm{TNS}^{0}$ to the head of MoodP in indicative clauses. The preverbal appearance of clitics in indicative clauses with a fronted focus, and in wh-interrogatives, presents empirical problems for this analysis.

${ }^{16}$ This fact also has diachronic implications. Philippaki-Warburton 1995 has suggested that the shift from enclisis to proclisis in Greek is due to the fact that modal particles like $n a$ become phonologically dependent on the verb, and cannot support an enclitic on their own. The Cappadocian data show that the causal connection is at any rate not a necessary one.

${ }^{17} \mathrm{~A}$ reviewer reminds us that the Oenountiaka variety of Pontic shows variation which is similar to the type A pattern (Oikonomides 1958:3,413).

${ }^{18}$ Miller 1992 argues from co-ordination data that French clitics are lexical. See also Auger 1995 and Miller and Sag 1997, and Labelle and Hirschbühler 2000 for an opposing view.

${ }^{19}$ As Drettas 1997:100 puts it: "On voit que ces phénomènes, obligatoires dans le cadre d'un paradigme donné (en l'occurrence, la conjugation d'un verbe), ne reproduisent pas forcément des contraintes phonologiques et que, par conséquant, on 
ne peut rendre compte au moyen d'une partie "règles phonologiques" de la langue; nous avons affaire à des faits morphologiques qui seront présentés avec les unités concernées (par example, l'article, l'objet verbal, etc.)." Drettas also argues against the claim that faz 'feeds' plus -sen 'you' is realized as faisen in order to avoid the prohibited sequence $*_{-} z s-$, on the grounds that one could achieve that by other means, for example, by inserting $e$ into the cluster. But clearly a process is not unmotivated just because another process might have achieved the same end. On the contrary, there are almost always multiple ways of avoiding constraint violations. For example, prohibited consonant clusters can be avoided by epenthesis, deletion, lenition, assimilation, or metathesis. Indeed, a language may use several of these devices under different conditions, depending on the ranking of its other constraints. But in any case, avoid-

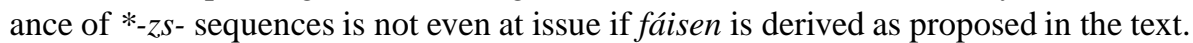
Thus, the argument based on avoidance of $*_{-} z s$ - is both fallacious and irrelevant. We conclude that Drettas has not made a good case for the affixal status of Pontic clitics.

${ }^{20}$ The haplological avoidance of $\ldots \mathrm{C}_{1} \mathrm{VC}_{1} \ldots$ sequences is probably a contributing factor (Oikonomides 1937). Drettas 105 cites evidence that such a haplology process applies productively across word boundaries, e.g., avúta ta pedía $\rightarrow$ avúta pedía. We emphasize, however, that our argument for the $\mathrm{X}^{0}$ status of Pontic clitics depends on the bare fact that /-sis/ and /-zis/ sequences are systematically reduced to -is in Pontic, and not on any particular analysis of that phonological reduction process.

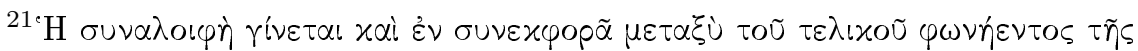

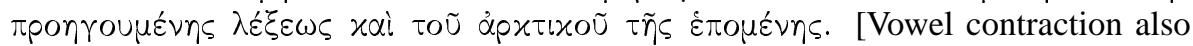
occurs between the final vowel of one word and the initial vowel of the following word.] (Papadopoulos 11).

${ }^{22}$ E.g., ámonto eksérts píson $\rightarrow$ ámont eksérts píson (Drettas 78,103).

${ }^{23}$ According to Horrocks 1990, the change from the ancient language to the medieval language is that the domain of cliticization shrinks from the sentential to the verbal domain: clitics in late Medieval Greek still appear in second position, as in Homeric Greek, but now in the second position of the VP (or of the verbal complex) rather than S. Horrocks links this change to the complementizer hina becoming the particle $n a$. Horrocks' idea, while appealingly simple, is dubious: as described below, clitics appear preverbally in the presence of Wh-phrases, preposed focused constituents, and negation, even if they are first within the verbal complex. See also Pappas 2001:135 for some pertinent remarks.

${ }^{24}$ Negation and wh-elements are the original V-to-C triggers in Germanic, and continue to trigger residual subject-aux inversion in English.

${ }^{25}$ The clitic mou adjoined to TNSP may be a possessive clitic raised from within the NP tin apasan ikian or a benefactive argument of the verb. Either analysis is compatible with our proposal.

${ }^{26}$ Across word boundary, [-s] (as well as the preceding obstruent in clusters like [-ks]) are voiced before voiced fricatives only. See Margariti-Ronga 1985:82,128 for 
a description of these voicing assimilation processes in the closely related dialect of Siatista.

${ }^{27} \mathrm{~A}$ small but suggestive piece of evidence is furnished by an observation of Pappas (2001:96) from 17th century Greek. In the periphrastic future, the clitic appears between $\theta e l o$ and the infinitive, and does not trigger secondary stress on the auxiliary, suggesting that it is attaching to the following nonfinite verb, as it is mutatis mutandis in Kozani. In Medieval Greek, on the other hand, as discussed by Mackridge and Pappas, the clitic follows the expected distribution with respect to the auxiliary. 


\section{References}

Alexiadou, Artemis. 1994. Adverbs in modern Greek. Doctoral dissertation, University of Potsdam.

Alexiadou, Artemis and Elena Anagnostopoulou. 1998. "Parametrizing Agr: word order, verb movement, and EPP checking." Natural Language and Linguistic Theory 16:491-539.

Anagnostopoulou, Eleni. 1994. Clitic Dependencies in Modern Greek. Doctoral dissertation, University of Salzburg.

Auger, Julie. 1995. "Les clitiques pronominaux en français parlé informel: une approche morphologique." Revue québecoise de linguistique 24:21-60.

Bošković, Željko. 2001. On the nature of the syntax-phonology interface. Amsterdam: Elsevier.

Černyševa, T.N. 1958. Novogrečeskij govor sel promorskogo (Urzufa) i Jalty, Pervomaiskogo raiona, Stalinskoj Oblasti. Kiev.

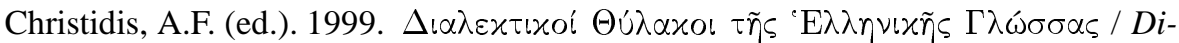
alect Enclaves of the Greek language. Athens: Centre for the Greek Language.

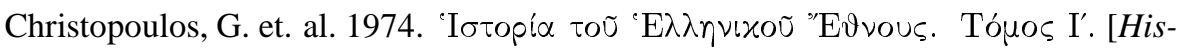

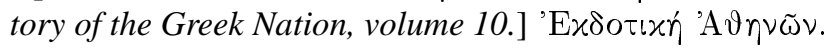

Danguitsis, Constantin. 1943. Etude descriptive du dialecte de Démirdési. Paris: Maisonneuve. [Dang]

Dawkins, Richard M. 1916. Modern Greek in Asia Minor. Cambridge: Cambridge University Press. [D]

Dawkins, Richard M. 1931. "Folk tales from Sourmena and the valley of Ophis." 'Apхعĩo По́vтou 3: 79-122.

Dawkins, Richard M. 1940. "The dialects of Modern Greek." Transactions of the Philological Society, 1-38.

Dawkins, Richard M. 1950. Forty-five stories from the Dodecanese. Cambridge: Cambridge University Press. [DD]

Drachman, Gaberell and Klidi, Sila. 1992. "The proper treatment of adverbial questions in Greek: The extended minimal structure hypothesis." Studies in Greek Linguistics 13:371-390.

Deo, Ashwini. 2001. “The development of IP in Indo-Aryan.” Manuscript, Stanford University.

Drettas, Georges. 1997. Aspects pontiques. Paris: Arp. [Dr]

Fontana, Josep M. 1993. Phrase structure and the syntax of clitics in the history of Spanish. Doctoral dissertation, University of Pennsylvania.

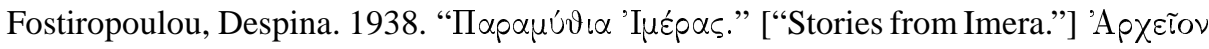
По́vтou 8:181-202.

Garrett, Andrew. 1995. Unpublished handout from NELS 24 Workshop on IndoEuropean. 
Giannakidou, Anastasia. 1998. Polarity sensitivity as (non)veridical dependency. Philadelphia: Benjamins.

Halpern, Aaron. 1995. On the placement and morphology of clitics. Stanford: CSLI Publications.

Halpern, Aaron and Josep M. Fontana. 1994. " $\mathrm{X}^{0}$ and $\mathrm{X}^{\max }$ clitics." WCCFL 12:251266.

Horrocks, Geoffrey C. 1990. "Clitics in Greek. A diachronic review." In M. Roussou and S. Panteli, eds., Greek Outside Greece II, 35-52. Athens: Diaspora Books.

Horrocks, Geoffrey. 1997. Greek: A History of its language and its people. London and New York: Longman.

Inkelas, Sharon. 1989. Prosodic constituency in the lexicon. Doctoral dissertation, Stanford University.

Janse, Mark. 1998. "Cappadocian clitics and the syntax-morphology interface." In Brian D. Joseph, Geoffrey C. Horrocks and Irene Philippaki-Warburton, eds., Themes in Greek Linguistics II, 257-281. Philadelphia: Benjamins.

Joseph, Brian. 1988. "Pronominal affixes in Modern Greek: the case against clisis." CLS 24, 203-215.

Katsoyannou, Marianna. 1999. "The idiom of Calabria.” In A.F. Christidis, ed., 113119.

King, Holloway Tracy. 1996. "Slavic clitics, long head movement, and prosodic inversion." Journal of Slavic Linguistics 4:274-311.

Kiparsky, Paul. 1995. "Indo-European origins of Germanic syntax.” In Adrian Battye and Ian Roberts, eds., Clause structure and language change. Oxford: Oxford University Press.

Kiparsky, Paul. 1996. "The shift to head-initial VP in Germanic." In Höskuldur Thráinsson, Samuel D. Epstein, and Steve Peter, eds., Studies in Comparative Germanic Syntax, Vol. 2.. Dordrecht: Kluwer.

Kiparsky, Paul. 1997. "The rise of positional licensing in Germanic.” In Ans van Kemenade and Nigel Vincent, eds., Parameters of morphosyntactic change. Cambridge: Cambridge University Press.

Kiparsky, Paul. To appear. "Finnish Noun Inflection." In Diane Nelson and Satu Manninen, eds., Generative Approaches to Finnic Linguistics. Stanford: CSLI Publications.

Kiparsky, Paul, Cleo Condoravdi, Anna Pliatsiou, Katerina Pliatsiou, Achilleas Theophanos, Fanis Katsanos, and Anastasia Kastanoulia. 2001. "The missing link: $\mathrm{X}^{0}$ proclitics in Kozani.” Manuscript.

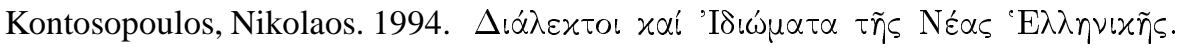
[Dialects and local varieties of Modern Greek.] Athens.

Kretschmer, Paul. 1905. Neugriechische Dialektstudien I: der heutige lesbische Dialekt. Wien: Akademie der Wissenschaften. [K]

Laka, Itziar. 1990. Negation in syntax: On the nature of functional categories and projections. Doctoral dissertation, MIT. 
Labelle, Marie and Paul Hirschbühler. 2000. "Les 'clitiques' arguments en serbocroate et dand l'histoire du français." In Claude Muller et al., eds., Clitiques et cliticization: actes du colloque du Bodeaux. Paris: Honoré Champion.

Lightfoot, David. 1999. The development of language: acquisition, change, and evolution. Oxford: Blackwell.

Mackridge, Peter. 1987. "Greek-speaking Moslems of north-east Turkey: prolegomena to a study of the Ophitic sub-dialect of Pontic." Byzantine and Modern Greek Studies 11:115-137.

Mackridge, Peter. 1993. "An editorial problem in medieval Greek: the position of the object clitic pronoun in the Escorial Digenes Akrites." In Nikolaos M. Panayio-

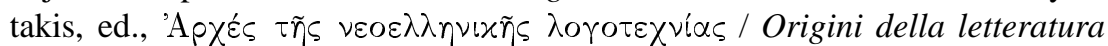
neogreca, 325-342. Venice.

Mackridge, Peter. 1999. "The Greek spoken in the region of Pontus.” In A.F. Christidis, ed., 101-105.

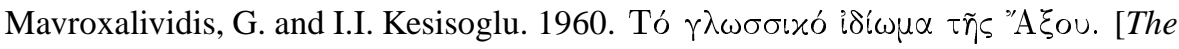
local dialect of Axos.] Athens: Kentro Mikrasiatikon Spoudon. [M \& K]

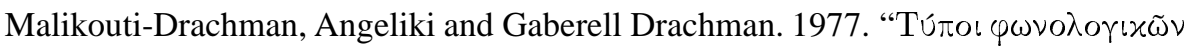

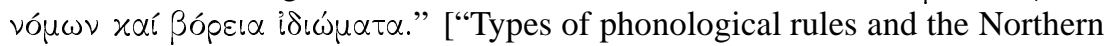

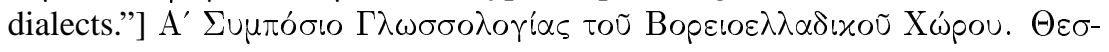
$\sigma \alpha \lambda o v i x \eta$.

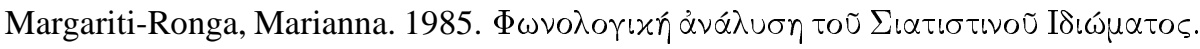
[Phonological analysis of the local dialect of Siatista.] Doctoral dissertation, Aristotelian University of Thessaloniki.

Miller, Philip H. 1992. "Postlexical cliticization vs. affixation: coordination criteria." CLS 28:382-396.

Miller, Philip H. and Ivan A. Sag 1997. "French clitic movement without clitics or movement." Natural Language and Linguistics Theory 15:573-639.

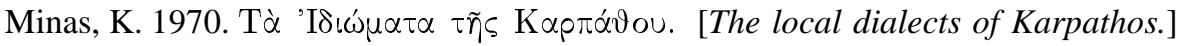
Athens: Klapakis.

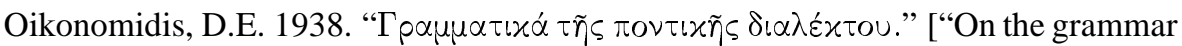
of the Pontic Dialect."] Pontiaka Phylla 2:200-206.

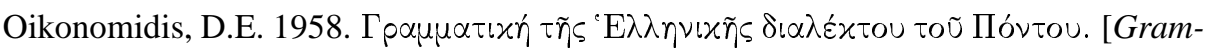
mar of the Greek dialect of Pontos.] Athens.

Ouspensky, Th. and V. Bénéchevitch. 1927. Actes de Vazélon/Vazelonskie Akty. Leningrad: Izdanie Gosudarstvennoj Publičnoj Biblioteki, Serija V: Orientalia, No. 2.

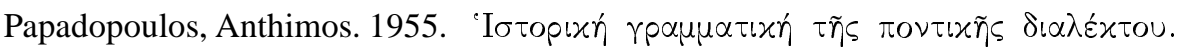
[Historical grammar of the Pontic dialect.] Athens. [P]

Pappas, Panayiotis. 2001. Weak object pronoun placement in Later Medieval and Early Modern Greek. Doctoral dissertation, The Ohio State University.

Pappou-Zouravliova, Ekaterini. 1999. "The Greeks of the Azov region and their language.” In A.F. Christidis, ed., 129-137. 
Philippaki-Warburton, Irene. 1985. "Word order in Modern Greek." Transactions of the Philological Society, 113-143.

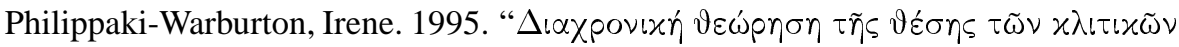
$\mu \varepsilon \varepsilon^{\prime} \sigma \alpha \tau \dot{n} \nu \pi p o ́ \tau \alpha \sigma \eta$." ["A diachronic view of the positioning of clitics within a

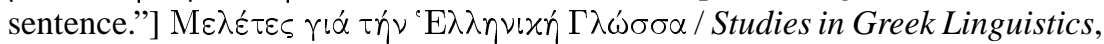
123-134. Thessaloniki: Aristotelian University.

Philippaki-Warburton, Irene and Vassilios Spyropoulos. 1999. "On the boundaries of inflection and syntax: Greek pronominal clitics and particles." In Geert Booij and Jaap van Marle, eds., Yearbook of Morphology 1998, 45-72. Boston: Kluwer Academic Publishers.

Piñón, Christopher. 1993. "SigmaP and Hungarian.” WCCFL 11:388-404.

Profili, Olga. 1999. "The revival of Grico in the Greek community of Salento." In A.F. Christidis, ed., 121-128.

Taylor, Ann. 1994. "The change from SOV to SVO in ancient Greek." Language Variation and Change 6:1-38.

Terzi, Arhonto. 1999. "Cypriot Greek clitics and their positioning restrictions." In Artemis Alexiadou, Geoffrey C. Horrocks and Melita Stavrou, eds., Studies in Greek Syntax, 227-240. Dordrecht: Kluwer.

Tomic, Olga. 2000. "On clitic sites." In Frits Beukema and Marcel den Dikken, eds., Clitic phenomena in European languages. Amsterdam: Benjamins.

Tsimpli, Ianthi Maria. 1995. "Focusing in Modern Greek." In Katalin É. Kiss, ed., Discourse configurational languages, 176-204. Oxford: Oxford University Press.

Tsimpli, Ianthi Maria, and Anna Roussou. 1996. "Negation and polarity items in Greek." The Linguistic Review 13: 49-81.

Veloudis, Ioannis. 1982. Negation in modern Greek. Doctoral dissertation, University of Reading.

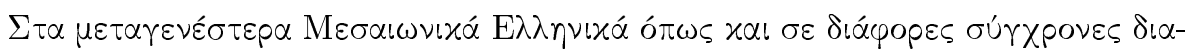

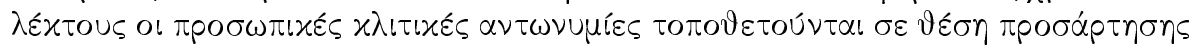

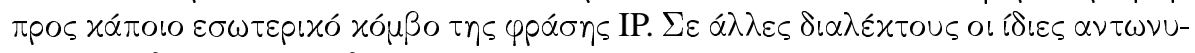

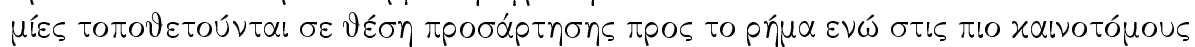

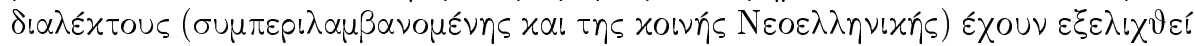

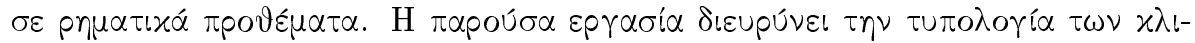

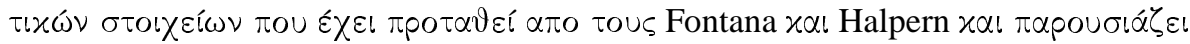

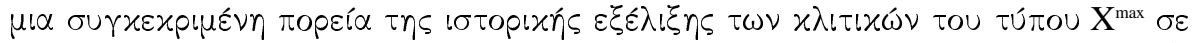

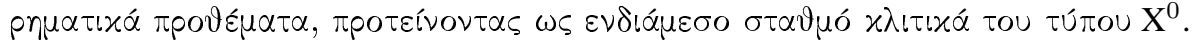

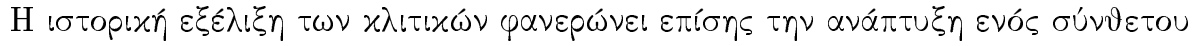

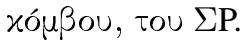

